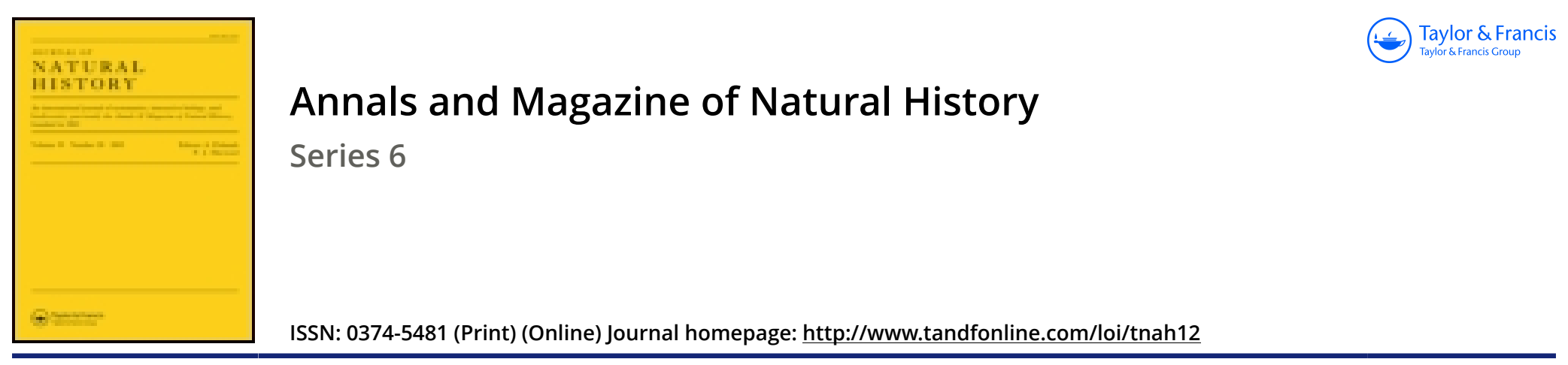

\title{
LXIV.-On the internal appendices of the genital apparatus of the Orthoptera
}

\section{M.A. Fénard}

To cite this article: M.A. Fénard (1896) LXIV.-On the internal appendices of the genital apparatus of the Orthoptera, Annals and Magazine of Natural History, 17:102, 450-452, DOI: $10.1080 / 00222939608680397$

To link to this article: http://dx.doi.org/10.1080/00222939608680397

册 Published online: 02 Oct 2009.

Submit your article to this journal $\lceil\pi$

Џ Article views: 4

Q View related articles $₫$ 
much smaller than the tympanum; first finger a little shorter than second; toes one-third webbed; subarticular tubercles moderately large, feebly prominent; a feebly prominent oval inner metatarsal tubercle, as long as the inner toe without the disk. The tibio-tarsal articulation reaches the nostril. Upper parts and throat granulate, some of the granules confluent into wavy longitudinal short ridges; belly and lower surface of limbs smooth. Greyish brown above, marbled with darker; limbs with rather irregular dark cross-bars; whitish beneath, throat and lower surface of limbs marbled with brown.

From snout to vent 30 millim.

A single female specimen.

\section{Nectophryne Everetti.}

Head small, as long as broad; snout short, prominent, obliquely truncate; canthus rostralis strong; loreal region vertical, concave; interorbital space broader than the upper eyelid; tympanum moderately distinct, one third the diameter of the eye. Fore limb very slender, nearly as long as the distance between the eye and the vent. Fingers slender, webbed at the base, feebly dilated and truncate at the end, first two thirds the length of second; toes nearly entirely webbed, scarcely dilated at the end; two very indistinct metatarsal tubercles. The tibio-tarsal articulation reaches the eye. Upper parts with scattered, small, horny tubercles; lower parts smooth. Olive-green above, with large, insuliform, reddish-brown, black-edged spots ; limbs with reddish-brown cross-bars; upper lip whitish, with reddish-brown vertical bars; dirty white beneath, throat and breast marbled with grey.

From snout to vent 33 millim.

A single female specimen.

LXIV.-On the Internal Appendices of the Genital Apparatus of the Orthoptera. By M. A. Fénard *.

There is an entomological question which for some long time has appeared to require to be taken up, and to which it will be useful to call attention, namely the internal appendices of the genital apparatus in male and female insects. I have during the past three years and more studied this matter, and have commenced with the order Orthoptera. I have the honour to communicate to the Academy some of the results obtained, confining myself for the present to the male organs.

* From the 'Comptes Rendus,' tome cxxii. 1896, pp. 894-895. 
I shall follow in this note the order of progressive complication of the organs studied.

Male Blattidæ exhibit no internal appendix to the vasa deferentia or to the ejecting canal ; this accords with the primitive characters of these insects.

In the Forficulidæ or Labiduræ I can confirm the statements of Meinert, accepted by Palmen, namely, that there is but one vesicula seminalis, that it is dependent on the vasa deferentia, that these are continued beyond and maintain a semblance of equal function; but I regard the organ which Meinert has named the nodiform gland as being nothing more than an apparatus for propelling the semen.

The family Acridide comes next: it forms a very special group, in which the series of modifications are but slightly marked in the series of genera. There is to be found between the two vasa deferentia a dozen tubulous cæca, drawn out, more or less sinuous, and passing from the ejaculatory canal in which they are inserted as far as the middle of the height of the testicles; they are arranged in two symmetrical masses, braced together and fitting the ventral face of the rectum. One pair only contains spermatozooids, the others contain a secretion and are (to be regarded as) glands. From the anatomical standpoint the vesiculæ seminales are whiter, more sinuous, more twisted, and gathered into knots at their free extremity.

'The Gryllidæ exhibit three kinds of appendices to the ejaculatory canal :-

1. Tubular cæca, to the number of a hundred on either side, in which spermatozooids are never seen, but only a secretion, which coagulates under the influence of mounting media and takes on the appearance of a very regular reticulum over a homogeneous mass, which often occludes a blackish powder consisting of crystals.

2. A large reniform vesicula seminalis, situate below the before-mentioned tubes, and in which the spermatozooids are placed.

3. A pair of prostatic glands on either side of the ejaculatory canal. In the group Gryllotalpidæ there are two vesiculæ seminales in place of one: these are the organs which some describe under the name of appendicular glands, and which may be seen crammed with spermatozooids a little before the rutting time.

The Locustidæ exhibit also three kinds of appendices to the ejaculatory canal: on the anterior part of the latter may be distinguished a large trunk which bifurcates; each of the two branches gives off almost immediately two branches, 
which are directed, one in front, the other behind: the first of these branches becomes the axis of the glandular tubes of the first order so-called; the second enlarges to form one or two oval reservoirs, into which there open some hundreds of glandular tubes of the second order so-called. These latter are barely $60 \mu$ in diameter ; they are but a third of the size of the others, but four times more numerous.

In the genera Ephippigera, Meconema, \&c. I have noticed in the midst of the tubes of the second order a special bundle more strongly coloured, formed by half a dozen cæca.

Lastly, in the Locustida there is to be found a pair of prostatic glands with a lenticular appearance.

In the Mantidæ there are four kinds of appendicular organs:-

1. Some fifty tubular cæca which are glandular.

2. About twenty shorter cæca gathered into knots, which are also glandular in character.

3. A pair of large vesiculæ seminales, which are concealed by the organs before mentioned.

4. A pair of prostatic glands.

From the histological point of view all these organs are, as a rule, made up of a single layer of cells supported on a basilar membrane; around the vesiculæ a peritoneal envelope is plainly visible.

There is a further remarkable fact, namely the development of very tiny crystals in the glandular tubes just before copulation.

LXV.-New Species of Pyralidæ from the Khasia Hills. By W. W ARren, M.A., F.E.S.

THE types of the species now described are, like those of $\mathrm{my}$ previous papers, in the possession of the Hon. Walter Rothschild. The majority, as will be seen, are from the Khasia Hills, a district whose richness appears to be by no means yet exhausted.

Family Pyralidæ.

Subfamily CHRYSAUGINA.

Genus Lophopalpia?, Hmpsn., MS.

Lophopalpia? chalybopicta, sp. $\mathbf{n}$.

Fore wings deep brown, with a strong chalybeous reflection 